Zeszyty Naukowe Szkoły Głównej Gospodarstwa Wiejskiego w Warszawie

Problemy Rolnictwa Światowego tom 18 (XXXIII), zeszyt 1, 2018: 224-234

DOI: 10.22630/PRS.2018.18.1.21

Aldona Skarżyńska $^{1}$, Lukasz Pietrych $^{2}$

${ }^{1}$ Instytut Ekonomiki Rolnictwa i Gospodarki Żywnościowej - Państwowy Instytut

Badawczy w Warszawie

${ }^{2}$ Szkoła Główna Gospodarstwa Wiejskiego w Warszawie

\title{
Projekcja opłacalności uprawy zbóż w Polsce w 2022 roku na tle prognozy produkcji zbóż w Unii Europejskiej do 2030 roku
}

\section{Projection of Profitability of Cereal Crops in Poland in 2022 against the Forecast of Cereal Production in the European Union in 2030}

\begin{abstract}
Synopsis. Celem badań było określenie wpływu prognozowanej zmiany cen środków do produkcji rolnej, plonów oraz cen sprzedaży produktów na opłacalność uprawy pszenicy ozimej, żyta ozimego i jęczmienia jarego w 2022 roku. Rezultaty badań wskazują na poprawę wyników produkcyjnych i cenowych badanych zbóż. Stwierdzono, że najsilniejszy wzrost przychodów odnotują producenci żyta. Zbadano również zakres odchyleń od wyników projekcji zbóż, ze względu na jednostkowe zmiany plonu, ceny i kosztów uprawy. Wyniki wskazują że żyto i jęczmień jary charakteryzuje dość duża wrażliwość na każdy z czynników dochodotwórczych, natomiast w przypadku pszenicy ozimej siła ich oddziaływania jest słabsza. Postępujące procesy integracji powoduja, że tego typu rozważania należy prowadzić $\mathrm{z}$ uwzględnieniem przewidywanych zmian na rynku unijnym. W związku z tym wyniki zaprezentowano na tle zmian jakie do 2030 roku przewiduje Komisja Europejska.
\end{abstract}

Słowa kluczowe: produkcja roślinna, modele trendu, prognozowanie

\begin{abstract}
The aim of the research was to determine the impact of the forecasted change in the prices of agricultural production, yield and product sales prices on the profitability of winter wheat, winter rye and spring barley in 2022. Research results indicate an improvement in the production and price results of the examined cereals. We calculate that the strongest forecasted revenue increase is observed in the case of rye producers. The range of deviations from cereal projection due to unit changes in yield, price and cultivation costs were also examined. The results indicate that rye and spring barley are characterized by quite high sensitivity to each of the income-generating factors, while in the case of winter wheat the strength of their impact is weaker. The progressive integration processes indicate that our considerations should take into account the anticipated changes on the EU market. Thus the results are presented in the light of predicted changes in the European Commission 2030 forecast.
\end{abstract}

Key words: cereal production, trend models, forecasting

JEL Classification: C53, Q13

\footnotetext{
${ }^{1}$ dr hab. inż., prof. IERIGŻ-PIB, Zakład Rachunkowości Rolnej, IERiGŻ-PIB, ul. Świętokrzyska 20, 00-002 Warszawa, e-mail: aldona.skarzynska@ierigz.waw.pl

${ }^{2}$ dr, Katedra Ekonomiki Rolnictwa i Międzynarodowych Stosunków Gospodarczych SGGW, ul. Nowoursynowska 166, 02-787 Warszawa, e-mail: lukasz_pietrych@sggw.pl, https://orcid.org/0000-0001-5053-3890
} 


\section{Wprowadzenie}

W Polsce w 2016 roku w strukturze towarowej produkcji rolniczej zboża ogółem stanowiły $11,3 \%$, a w towarowej produkcji roślinnej 27,1\%. Natomiast udział zbóż podstawowych w towarowej produkcji zbóż ogółem wynosił 80,9\%, wśród nich udział pszenicy wynosił 70,2\%, żyta - 9,4\%, jęczmienia - 9,1\%, a łączny udział owsa i pszenżyta - 11,3\% (Rocznik Statystyczny, 2017). Polska należy do grupy krajów, w których zboża są najbardziej znaczącą grupą roślin uprawnych, a produkcja zbożowa dla wielu gospodarstw jest najważniejszym źródłem dochodów. Podaż i popyt na rynku zbóż ma znaczenie dla całej gospodarki żywnościowej. Ceny zbóż determinują koszty produkcji zwierzęcej i mają wpływ na opłacalność produkcji żywca wieprzowego i drobiu. Wielkość zbiorów zbóż i ich ceny wyznaczają więc poziom dochodów gospodarstw w sposób bezpośredni i pośredni.

Według Majewskiego (2010) rolnictwo w krajach Unii Europejskiej (UE) jest zdominowane przez uprawy zbożowe, średni ich udział w powierzchni zasiewów w 2007 roku kształtował się na poziomie $77 \%$. Z badań wynika, że produkcja większości zbóż pokrywa potrzeby rynku wewnętrznego UE, wskaźnik samowystarczalności dla zbóż ogółem wynosi 103\%, z wyjątkiem kukurydzy, dla której stopień samowystarczalności kształtuje się na poziomie 87,3\% (Baer-Nawrocka i Kiryluk-Dryjska, 2015; za: Eurostat ..., 2015).

Uprawie zbóż sprzyja relatywnie łatwa technologia produkcji, względnie niska pracochłonność, a także łatwość przechowywania i transportu. Jednak decyzje podejmowane przez rolnika zawsze wiążą się z ryzykiem, co do uzyskanych rezultatów. Wynika to z rozbieżności, pomiędzy czasem kiedy decyzje są podejmowane, a czasem kiedy pojawiają się skutki tych decyzji.

Prognozy i projekcje $e^{3}$ dzięki uzyskiwanym przy ich pomocy informacjom są przydatne w zarządzaniu gospodarstwem rolnym. Odgrywają ważną rolę przy określaniu konsekwencji podejmowanych decyzji, tzn. spodziewanych korzyści i koniecznych do poniesienia kosztów. Według Sobczyka (2008) nawet, gdy prognozy nie są trafne, to uświadamiają jakie trendy, mogą kształtować prognozowane zjawisko w najbliższych latach. Dzięki temu istnieje możliwość podjęcia działań zmierzających do eliminacji zdarzeń negatywnych. Wyniki prognoz gospodarczych powinny przede wszystkim inspirować do podjęcia działań zmierzających do utrwalenia kierunku rozwoju uznanego za korzystny lub do przeciwdziałania kierunkowi rozwoju, który uznaje się za niepożądany.

Jak zauważa Allen (1994) odbiorcami prognoz dotyczących produkcji rolnej mogą być rolnicy oraz różne podmioty działające w sektorze agrobiznesu. Jednak ze względu na szczególną pozycję gospodarki żywnościowej w umacnianiu bezpieczeństwa kraju, ośrodki decyzyjne kształtujące politykę rolną są głównym kreatorem i użytkownikiem prognoz. Opracowane prognozy są pomocne w trakcie definiowania celów polityki gospodarczej oraz jej realizacji.

Celem badań było określenie dynamiki zmian cen środków do produkcji rolnej, zmian plonów i cen produktów rolnych w perspektywie średnioterminowej oraz jej wpływu na opłacalność uprawy pszenicy ozimej, żyta ozimego i jęczmienia jarego prognozowanej w perspektywie 2022 roku. Zbadano także zakres odchyleń od wyników projekcji zbóż wynikających z trendu (tzn. od poziomu przewidywanego na 2022 rok), ze względu na

\footnotetext{
${ }^{3}$ Projekcja podobnie jak prognoza jest terminem odnoszącym się do przewidywania przyszłości. Stańko (1999, s. 8) definiuje projekcje jako ,uproszczone, niekiedy schematyczne przeniesienie obrazu przeszłości w przyszłość”.
} 
jednostkowe zmiany plonu, ceny i kosztów uprawy. Wyniki zaprezentowano na tle zmian jakie do 2030 roku przewiduje Komisja Europejska.

\section{Dane i metody}

Do realizacji sformułowanego celu wykorzystano dane pierwotne oraz dane wtórne. Dane pierwotne zostały zgromadzone i przetworzone według założeń systemu AGROKOSZTY $^{4}$. Dotyczyły one produkcji pszenicy ozimej, żyta ozimego oraz jęczmienia jarego w latach 2013-2015. Bazę tę uzupełniono danymi z bazy Polskiego FADN, a następnie przetworzono zgodnie z opracowaną dla produktów rolniczych metodą rachunku kosztów. Przyjęto założenie o niezmienności struktury i ilości nakładów poniesionych na produkcję, co oznacza, że nakłady odzwierciedlają średni poziom w latach 2013-2015.

Punktem wyjścia do projekcji wyników ekonomicznych na 2022 rok był średni poziom kosztów uprawy (bezpośrednich i pośrednich) oraz składników wartości produkcji (plonu i ceny) z lat 2013-2015. Zastosowanie takiego podejścia pozwala uniknać zaniżonych, bądź też zawyżonych wartości prognozy (Sobczyk, 1976). Dane niezbędne do wyznaczenia linii trendu były danymi wtórnymi zaczerpniętymi głównie z opracowań statystyki publicznej. Dodatkowo na potrzeby niniejszej pracy przyjęto, że przez pojęcie danych należy rozumieć zmienne, które generują określony poziom wartości produkcji (plon i cena) oraz składniki kosztów bezpośrednich i pośrednich. W przypadku cen produktów były to ceny skupu, a cen środków do produkcji - ceny ich sprzedaży (Skarżyńska i Pietrych, 2017).

Korzystając z danych wtórnych zaczerpniętych ze statystyki publicznej, do zmiennych opisujących poszczególne produkty (stanowiące punkt wyjścia dla projekcji) przyporządkowano odpowiednie szeregi czasowe obejmujące okres od 1995 do 2015 roku. Szeregi czasowe pozwoliły na budowę modeli tendencji rozwojowej oraz ekstrapolację w przyszłość analizowanych zmiennych. W związku z tym, dla każdego z produktów oraz odpowiadającym im składnikom wartości produkcji i kosztów wybrano model, który możliwie najtrafniej opisuje zmienność badanego zjawiska.

Modele ekstrapolacji funkcji trendu w literaturze przedmiotu są określane, jako najprostszy sposób prognozowania zjawisk charakteryzujących się trendem (Hamulczuk, Klimowski i Stańko, 2013). Wymagają one jednak przyjęcia założenia, że postać analityczna funkcji i wartości jej parametrów w okresie prognozowanym nie mogą ulec istotnej zmianie w porównaniu z okresem na podstawie, którego oszacowano model trendu (Sobczyk, 1991). Ważną cechą metod opartych na modelach szeregów czasowych jest także budowanie prognozy na podstawie prawidłowości zaobserwowanych $\mathrm{w}$ dotychczasowej dynamice prognozowanego zjawiska, bez wnikania w przyczyny ich występowania (Filipiak, 2009).

\footnotetext{
${ }^{4}$ Badania rolniczych działalności produkcyjnych w systemie AGROKOSZTY prowadzone są w indywidualnych gospodarstwach rolnych wybieranych celowo z reprezentatywnej próby, która znajduje się w polu obserwacji polskiego FADN. Dobór gospodarstw do badań każdej działalności produkcyjnej dokonywany jest niezależnie. Warunkiem doboru jest prowadzenie wybranej do badań działalności i określona skala jej produkcji. Gospodarstwa uczestniczące w badaniach położone sa na terenie całego kraju, nie stanowią jednak - ze względu na sposób doboru - reprezentatywnej próby dla gospodarstw indywidualnych w Polsce prowadzących określoną działalność, np. uprawiających pszenicę ozimą. W systemie AGROKOSZTY gromadzone są ilościowe i wartościowe dane o poziomie produkcji, poniesionych nakładach i kosztach bezpośrednich w odniesieniu do działalności produkcji roślinnej i zwierzęcej. Dane te zbierane są według jednolitych założeń z precyzyjnie wyznaczonymi standardami i dokładnie określoną metodyką.
} 
Oznacza to, że odchylenia od trendu mają jedynie charakter losowy, co w przypadku modelu addytywnego można zapisać następująco (Hamulczuk, Klimowski i Stańko, 2013):

$$
Y_{t}=f(t)+\varepsilon_{t},
$$

gdzie: $Y_{t}$ - obserwowane zjawisko w czasie $\mathrm{t}$ (wartość teoretyczna wynikająca z modelu), $f(t)$ - szacowana funkcja trendu, $\varepsilon_{t}$ - składnik losowy w czasie t.

W badaniu rozpatrywano siedem funkcji: liniowa, kwadratowa, wykładnicza, potęgowa, logarytmiczna, hiperboliczną i liniowo-hiperboliczną. Na podstawie oszacowań tych funkcji, dla każdego z rozpatrywanych szeregów czasowych wybrano model trendu najlepiej opisujący analizowaną zmienną.

Wybór odpowiedniej postaci funkcji trendu, w pierwszym kroku odbywał się na podstawie analizy graficznej, czyli obserwacji położenia w układzie współrzędnych punktów odpowiadających zebranym obserwacjom. Jak stwierdza Stańko (1999) układ tych punktów informuje o charakterze zależności. Należy zauważyć, że przykładowo modele o postaci analitycznej kwadratowej funkcji trendu lub liniowo-hiperbolicznej cechują się zazwyczaj silnym prognozowanym wzrostem zmiennej objaśnianej $\mathrm{w}$ horyzoncie prognozy, co w przypadku prognozowania wielkości produkcji, czy poziomu kosztów zazwyczaj nie znajduje racjonalnego uzasadnienia.

Analiza wykresu wraz ze znajomością przebiegu określonych funkcji upoważnia do sformułowania hipotezy dotyczącej postaci analitycznej funkcji trendu. Sprawdzenie słuszności tej hipotezy następuje w toku estymacji parametrów modelu oraz statystycznej weryfikacji jego jakości (Dittmann, 2004). W związku z tym, w kolejnym kroku analizowano statystyczną istotność parametrów funkcji trendu oraz stopień dopasowania modelu do danych empirycznych (współczynnik determinacji, skorygowany współczynnik determinacji oraz współczynnik zmienności losowej $\mathrm{V}_{\mathrm{e}}$ ) (Kisielińska, 2012).

Według literatury przedmiotu weryfikacja formalno-statystyczna nie jest w tym przypadku wystarczająca. Sugeruje się, aby proces wyznaczania funkcji trendu nie opierać na jednej metodzie (lub jednym kryterium), ale na kilku kryteriach stosowanych jednocześnie (Stańko, 1999). Dittmann (2004) podkreśla, że przy wyborze postaci funkcji trendu należy brać pod uwagę zarówno przesłanki empiryczne jak i dedukcyjne, z tym, że przy bardziej złożonych funkcjach trendu powinny przeważać przesłanki dedukcyjne, a przy mniej złożonych - przesłanki empiryczne. Umożliwia to uniknięcie wyboru bardziej złożonej postaci analitycznej funkcji, jedynie na podstawie analizy wykresu szeregu czasowego. Konieczne jest również uwzględnienie mechanizmu rozwojowego analizowanego zjawiska w czasie.

W literaturze przedmiotu, często obok konieczności przeprowadzenia weryfikacji formalno-statystycznej postuluje się przeprowadzenie również tzw. weryfikacji merytorycznej. Oznacza to, że znaki oraz wielkość oszacowanych parametrów strukturalnych stojących przy zmiennych objaśniających ( $\mathrm{w}$ przypadku modeli trendu jest to jedynie zmienna czasowa t) mają sens ekonomiczny. Jednakże w przypadku funkcji trendu, tego typu weryfikacja jest ograniczona (Stańko i Hamulczuk, 2013).

Kierując się wyżej opisanymi przesłankami, dla każdej zmiennej wybrano najodpowiedniejszą postać funkcji trendu. Weryfikacji statystycznej modeli tendencji 
rozwojowej dokonano za pomocą testu t-Studenta (istotność statystyczna parametrów strukturalnych) oraz testu $\mathrm{F}$ (istotność statystyczna całego modelu) ${ }^{5}$.

Mając już odpowiednie modele dla każdego z szeregów czasowych, obliczono wartości teoretyczne wraz z ich prognozą do roku 2022, a następnie obliczono łańcuchowe indeksy zmian. Otrzymane indeksy zastosowano do przeliczenia wartości z przyjętego punktu startowego na lata stanowiące horyzont prognozy. Pozwoliło to na uzyskanie projekcji wszystkich składników struktury wartości produkcji i kosztów produkcji pszenicy ozimej, żyta ozimego oraz jęczmienia jarego. $\mathrm{W}$ ostatnim etapie obliczono prognozowane na rok 2022 wyniki ekonomiczne badanych działalności.

\section{Produkcja i ceny zbóż w UE - projekcja do 2030 roku}

Średnio w latach 2010-2017 produkcja zbóż w Unii Europejskiej wynosiła 300777 tys. ton, z tego 69,0\% wytworzone zostało w krajach „starej Unii” (UE-15), a 31,0\% w krajach, które przystapiły do UE po 2004 roku (UE-N13). Główni producenci zbóż we Wspólnocie to Francja i Niemcy, z produkcją stanowiącą odpowiednio 22,1 i 15,4\% produkcji ogółem w UE. Polska pod względem wielkości produkcji, w UE-28 zajęła pozycję trzecią z udziałem wynoszącym 9,7\%, natomiast pozycję pierwszą wśród krajów UE-N13 - z udziałem 31,3\% (European ..., 2018).

$\mathrm{Z}$ danych zawartych w tabeli 1 wynika, że do 2030 roku Komisja Europejskiej (KE) przewiduje systematyczny wzrost produkcji zbóż, w porównaniu z rokiem 2017, w UE-28 o 13,1\% (w UE-15 o 9,3\%, a w UE-N13 o 21,2\%). Według KE wzrost produkcji zbóż nastąpi ze względu na większe zapotrzebowanie na ziarno paszowe (szczególnie kukurydzy) oraz dobre perspektywy eksportowe (szczególnie pszenicy). Silniejszy - niż prognozowany - wzrost produkcji jest ograniczony przez stopniowe zmniejszanie się dostępnych gruntów ornych oraz słabszy wzrost plonu w porównaniu do innych regionów świata. Większych wzrostów plonu ziarna można oczekiwać tylko w krajach UE-N13, ponieważ w UE-15 produkcyjność zbóż zbliża się do agro-ekonomicznego maksimum (European ..., 2016).

Wyniki prognozy wskazują że w roku 2030 w porównaniu z rokiem 2017 produkcja pszenicy zwyczajnej w UE zwiększy się o 13,6\% (w UE-15 o 10,2\%, a w UE-N13 o 21,3\%). $\mathrm{W}$ znacznym stopniu przyczyni się do tego wyższy o $8,3 \%$ plon ziarna. W krajach UE-15 plon pszenicy może wzrosnąć o 5,9\% w stosunku do 2017 roku (z 6,8 do 7,2 t/ha), podczas gdy w UE-N13 - o $12,5 \%$ (z 4,8 do 5,4 t/ha). Cena ziarna też będzie systematycznie rosła i w docelowym roku prognozy przewyższy poziom z 2017 roku o $16,9 \%$. Pozostanie jednak nadal niższa w porównaniu do korzystnego poziomu z 2010 roku.

\begin{tabular}{|c|c|c|c|c|c|c|}
\hline Zmienna objaśniana & Postać funkcji trendu & $R^{2}$ & $V_{e}[\%]$ & test $\mathrm{t}$ - & udenta & test $\mathrm{F}$ \\
\hline plon pszenicy ozimej & $\begin{array}{l}\text { liniowy: } \\
f(t)=31,62+0,57 t\end{array}$ & 0,67 & 6,31 & $\begin{array}{l}b_{0} \\
b_{1}\end{array}$ & $\begin{array}{l}* * * \\
* * *\end{array}$ & $* * *$ \\
\hline cena pszenicy ozimej & $\begin{array}{l}\text { wykładniczy: } \\
f(t)=1 E-22 e^{0,03 t}\end{array}$ & 0,43 & 18,38 & $\begin{array}{l}b_{0} \\
b_{1}\end{array}$ & $\begin{array}{l}* * * \\
* * *\end{array}$ & $* * *$ \\
\hline
\end{tabular}


Tabela 1. Produkcja, plon i ceny zbóż w UE w latach 2010-2017 oraz projekcja do 2030 roku

Table 1. Production, yield and cereal prices in the EU in 2010-2017 and projection by 2030

\begin{tabular}{|c|c|c|c|c|c|c|c|c|c|c|}
\hline Wyszczególı & nienie & 2010 & 2015 & 2017 & 2020 & 2022 & 2024 & 2026 & 2028 & 2030 \\
\hline \multicolumn{11}{|c|}{ Zboża ogółem } \\
\hline \multicolumn{2}{|l|}{ Produkcja, mln. ton } & 281,2 & 314,4 & 301,2 & 317,2 & 322,0 & 326,6 & 331,3 & 336,1 & 340,8 \\
\hline \multirow[t]{2}{*}{$\mathrm{z}$ tego: } & w EU-15 & 199,7 & 218,4 & 203,4 & 213,9 & 215,7 & 217,3 & 218,9 & 220,7 & 222,4 \\
\hline & w EU-N13 & 81,5 & 96,0 & 97,7 & 103,3 & 106,3 & 109,4 & 112,4 & 115,4 & 118,4 \\
\hline \multicolumn{11}{|c|}{ Pszenica zwyczajna } \\
\hline \multicolumn{2}{|l|}{ Produkcja, mln. ton } & 127,8 & 152,5 & 141,5 & 148,9 & 151,2 & 153,5 & 155,9 & 158,3 & 160,7 \\
\hline \multirow[t]{2}{*}{$\mathrm{z}$ tego: } & w EU-15 & 95,8 & 107,8 & 98,3 & 103,2 & 104,2 & 105,2 & 106,2 & 107,3 & 108,3 \\
\hline & w EU-N13 & 32,0 & 44,7 & 43,2 & 45,7 & 47,0 & 48,4 & 49,7 & 51,1 & 52,4 \\
\hline \multicolumn{2}{|l|}{ Plon, $\mathrm{t} / \mathrm{ha}$} & 5,5 & 6,3 & 6,0 & 6,1 & 6,2 & 6,3 & 6,3 & 6,4 & 6,5 \\
\hline \multirow[t]{2}{*}{$\mathrm{z}$ tego: } & w EU-15 & 6,6 & 7,2 & 6,8 & 6,9 & 7,0 & 7,0 & 7,1 & 7,1 & 7,2 \\
\hline & w EU-N13 & 3,7 & 4,7 & 4,8 & 4,9 & 5,0 & 5,1 & 5,2 & 5,3 & 5,4 \\
\hline \multicolumn{2}{|l|}{ Cena, EUR/tonę } & 230 & 160 & 166 & 171 & 181 & 187 & 189 & 192 & 194 \\
\hline \multicolumn{11}{|c|}{ Jęczmień } \\
\hline \multicolumn{2}{|l|}{ Produkcja, mln. ton } & 53,1 & 61,9 & 58,6 & 61,0 & 61,9 & 62,5 & 63,2 & 64,0 & 64,8 \\
\hline \multirow[t]{2}{*}{$\mathrm{z}$ tego: } & w EU-15 & 43,3 & 50,5 & 47,4 & 49,1 & 49,7 & 50,0 & 50,4 & 50,8 & 51,3 \\
\hline & w EU-N13 & 9,8 & 11,5 & 11,2 & 11,9 & 12,2 & 12,5 & 12,8 & 13,2 & 13,5 \\
\hline Plon, $\mathrm{t} / \mathrm{ha}$ & & 4,3 & 5,1 & 4,8 & 5,0 & 5,0 & 5,1 & 5,1 & 5,2 & 5,3 \\
\hline \multirow[t]{2}{*}{$\mathrm{z}$ tego: } & w EU-15 & 4,7 & 5,4 & 5,0 & 5,2 & 5,2 & 5,3 & 5,3 & 5,3 & 5,4 \\
\hline & w EU-N13 & 3,2 & 4,1 & 4,1 & 4,3 & 4,4 & 4,5 & 4,6 & 4,7 & 4,9 \\
\hline Cena, EUR/tonę & & 190 & 153 & 138 & 150 & 161 & 162 & 165 & 168 & 169 \\
\hline
\end{tabular}

Źródło: (Prospects for Agricultural ..., 2017).

Produkcja jęczmienia również będzie większa, w 2030 roku o 10,6\% przewyższy poziom z 2017 roku. Wzrost produkcji, podobnie jak w przypadku pszenicy, silniejszy będzie w krajach „nowej unii” (UE-N13). Wzrost plonu również będzie silniejszy - może wynieść 19,5\% (z 4,1 do 4,9 t/ha), podczas gdy w krajach UE-15 - 8,0\% (z 5,0 do 5,4 t/ha). Według KE cena jęczmienia wzrośnie o $22,5 \%$ i ukształtuje się na poziomie 169 euro/tonę.

\section{Opłacalność uprawy pszenicy ozimej, żyta ozimego i jęczmienia jarego w Polsce - projekcja na 2022 rok}

Zastosowana metoda projekcji - przez ekstrapolację tendencji zaobserwowanej w przeszłości - pozwoliła określić spodziewany kierunek zmiany po stronie przychodów i kosztów, a następnie przewidywaną wysokość dochodu i ekonomiczną efektywność produkcji badanych zbóż w 2022 roku - tabela 2, rys. 1.

Według projekcji sporządzonej na 2022 rok dla pszenicy ozimej wartość produkcji, czyli przychody z 1 ha jej uprawy, z roku na rok będą przyrastać w granicach 4,0-4,1\% (przy przyrostach plonu w granicach 1,2-1,3\%, a ceny ziarna 2,8\%) i w 2022 roku w porównaniu do roku bazowego dla projekcji (2015) - wzrosną o 31,9\%. Roczny wzrost 
kosztów ogółem w analizowanym okresie ocenia się na 2,8-3,1\%, w konsekwencji mogą one przewyższyć poziom roku bazowego o 22,4\%. Oznacza to, że w perspektywie 2022 roku należy spodziewać się silniejszej o 9,5 p.p. dynamiki wzrostu przychodów niż kosztów. W rezultacie dochód $\mathrm{z}$ uprawy pszenicy, w stosunku do roku bazowego dla projekcji, może być wyższy o $56,2 \%$ (w próbie badawczej gospodarstw osiagnie poziom 1954 zł/ha). Efektywność ekonomiczna produkcji pszenicy również poprawi się, wskaźnik opłacalności (procentowa relacja wartości produkcji do kosztów ogółem) będzie wyższy niż w roku bazowym o 10,8 p.p.

Tabela 2. Wyniki uprawy zbóż w roku bazowym 2015* oraz projekcja na 2022 rok (w cenach bieżących)

Table 2. The results of cereal crop in the base year $2015 *$ and the projection for 2022 (in current prices)

\begin{tabular}{|c|c|c|c|c|c|c|c|}
\hline \multirow[t]{2}{*}{ Wyszczególnienie } & & $\begin{array}{c}\text { Rok } \\
2015^{*}\end{array}$ & $\begin{array}{c}\text { Projekcja } \\
\text { na rok } \\
2022\end{array}$ & $\begin{array}{c}\text { Rok } \\
2015^{*}\end{array}$ & $\begin{array}{c}\text { Projekcja } \\
\text { na rok } \\
2022\end{array}$ & $\begin{array}{c}\text { Rok } \\
2015^{*}\end{array}$ & $\begin{array}{c}\text { Projekcja } \\
\text { na rok } \\
2022\end{array}$ \\
\hline & & \multicolumn{2}{|c|}{ Pszenica ozima } & \multicolumn{2}{|c|}{ Żyto ozime } & \multicolumn{2}{|c|}{ Jęczmień jary } \\
\hline \multicolumn{2}{|l|}{ Liczba gospodarstw w badaniach } & \multicolumn{2}{|c|}{144} & \multicolumn{2}{|c|}{113} & \multicolumn{2}{|c|}{155} \\
\hline Powierzchnia uprawy & [ha] & \multicolumn{2}{|c|}{23,85} & \multicolumn{2}{|c|}{11,52} & \multicolumn{2}{|c|}{9,85} \\
\hline Plon ziarna & [dt/ha] & 65,5 & 71,5 & 36,7 & 41,4 & 46,2 & 48,4 \\
\hline Cena sprzedaży ziarna & {$[\mathrm{zt} / \mathrm{dt}]$} & 67,59 & 81,73 & 49,79 & 63,37 & 61,62 & 71,83 \\
\hline Wartość produkcji & {$[\mathrm{zt} / \mathrm{ha}]$} & 4442 & 5860 & 1848 & 2646 & 2872 & 3502 \\
\hline \multirow{2}{*}{$\begin{array}{l}\text { Koszty ogółem } \\
\text { (bezpośrednie + pośrednie) }\end{array}$} & {$[\mathrm{zt} / \mathrm{ha}]$} & 3191 & 3906 & 1414 & 1722 & 2120 & 2606 \\
\hline & {$[\mathrm{zt} / \mathrm{dt}]$} & 48,72 & 54,63 & 38,53 & 41,59 & 45,89 & 53,84 \\
\hline \multirow{2}{*}{ Dochód z działalności bez dopłat } & {$[\mathrm{zt} / \mathrm{ha}]$} & 1251 & 1954 & 435 & 924 & 752 & 896 \\
\hline & {$[\mathrm{zt} / \mathrm{dt}]$} & 19,10 & 27,33 & 11,85 & 22,32 & 16,28 & 18,51 \\
\hline $\begin{array}{l}\text { Koszty ogółem wytworzenia } 1 \text { zł } \\
\text { dochodu z działalności bez dopłat }\end{array}$ & {$[\mathrm{zł}]$} & 2,55 & 2,00 & 3,25 & 1,86 & 2,82 & 2,91 \\
\hline
\end{tabular}

* 2015 rok - bazowy dla modelu projekcji, wyniki odzwierciedlają średnie w latach 2013-2015.

Źródło: opracowano na podstawie badań własnych.

Ocenia się, że w perspektywie 2022 roku przychody z uprawy żyta ozimego mogą przyrastać rocznie w granicach 5,2-5,3\%, w efekcie w porównaniu z rokiem bazowym dla projekcji wzrosną o $43,2 \%$. Zadecyduje o tym wyższy plon, który rocznie będzie przyrastał w granicach 1,7-1,8\% oraz przyrosty ceny ziarna zbliżone do 3,5\%. Koszty ogółem uprawy 1 ha przy rocznych przyrostach od 2,7 do $3,1 \%$ wzrosną o $21,8 \%$ w stosunku do 2015 roku. Oznacza to, że w perspektywie 2022 roku należy spodziewać się silniejszej o 21,4 p.p. dynamiki wzrostu przychodów niż kosztów. W tej sytuacji dochód bez dopłat jaki uzyskają producenci żyta w 2022 roku będzie przewyższał poziom z roku bazowego aż o $112,4 \%$. Natomiast wskaźnik opłacalności produkcji żyta osiagnie poziom 153,7\%, czyli będzie wyższy niż w roku bazowym dla projekcji $(130,7 \%)$ o 23,0 p.p.

Do 2022 roku wzrost z roku na rok przychodów z uprawy jęczmienia jarego może wynosić $2,8-3,0 \%$ (roczne przyrosty ceny ziarna wyniosą od 2,1 do $2,3 \%$, a plonu będą zbliżone do $1 \%$ ), podczas gdy koszty ogółem uprawy 1 ha będą przyrastać rocznie w granicach $2,9-3,2 \%$. Oznacza to, że w roku 2022 - w porównaniu z rokiem bazowym projekcji - przychody mogą być wyższe o $21,9 \%$, a koszty - o $22,9 \%$. Pomimo, że dynamika wzrostu kosztów będzie silniejsza niż przychodów, przewiduje się, że w 2022 
roku dochód z działalności będzie stanowił 119,1\% poziomu uzyskanego w roku bazowym (może wynieść $896 \mathrm{zł} / \mathrm{ha}$ ). Pogorszy się jednak efektywność ekonomiczna produkcji. Wskaźnik opłacalności obniży się o 1,1 p.p., co oznacza, że wzrost wartości produkcji nastapi w zbyt kosztowny sposób.

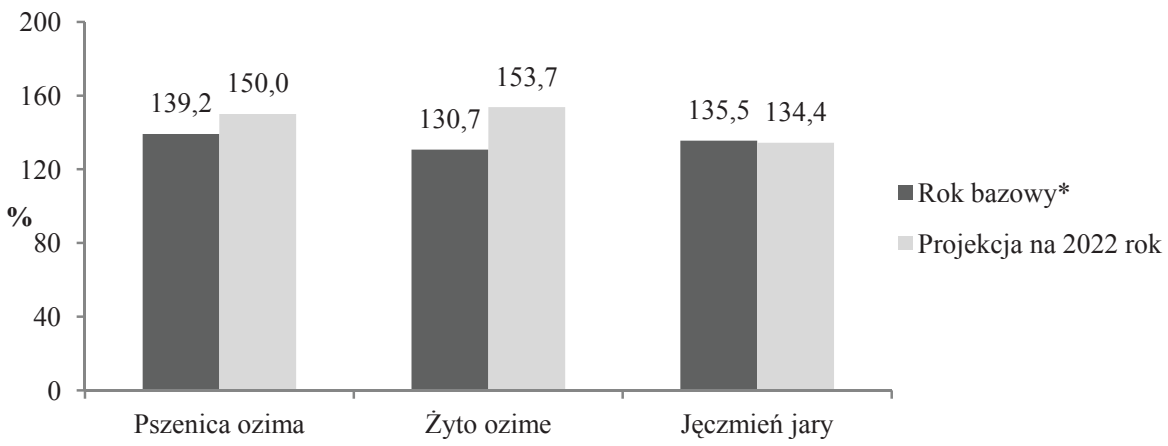

* 2015 rok - bazowy dla modelu projekcji, wyniki odzwierciedlają średnie w latach 2013-2015.

Rys. 1. Wskaźnik opłacalności uprawy zbóż w bazowym roku 2015 oraz projekcja na 2022 rok

Fig. 1. Profitability ratio of cereal crops in the base year 2015 and projection for 2022

Źródło: opracowano na podstawie badań własnych.

Od wyników przewidywanych na 2022 rok, a wynikających $\mathrm{z}$ tendencji długookresowej mogą jednak występować znaczne odchylenia. W trakcie wegetacji roślin zmienne warunki pogodowe często powodują, że plon podlega dużym wahaniom. Ceny produktów oraz koszty uprawy także mogą się zmieniać, a dynamika tych zmian nie musi odzwierciedlać trendu obserwowanego w ostatnich latach. W rolnictwie nie można opracować pewnej prognozy, można jednak przewidywać granice zmienności i obserwować kierunek zmian uzyskanych efektów. Dlatego zbudowano modele, które pozwoliły określić siłę oddziaływania na zakres zmiany (in plus oraz in minus) dochodu i wskaźnika opłacalności produkcji badanych zbóż, poszczególnych czynników go determinujących, tj. plonu, ceny i kosztów uprawy. Należy jednak zauważyć, że na zakres prezentowanych zmian, wpływ mają także dane, które były punktem wyjścia do przeprowadzenia badań. Oznacza to, że prezentowane zmiany odnoszą się wyłącznie do próby badawczej gospodarstw. Niemniej jednak dają obraz sytuacji i jej skutków, wskazują jednocześnie na duże ryzyko interpretacji wyników projekcji w dosłowny sposób, tzn. traktując dane liczbowe jako pewne - tabela 3.

Z badań wynika, że zmiana plonu o jednostkę ( $1 \mathrm{dt})$ będzie miała najsilniejszy wpływ (dodatni lub ujemny) na wysokość dochodu z uprawy jęczmienia jarego $(+/-8,1 \%)$ i żyta (+/-6,8\%), czyli zbóż, których plon był niższy w porównaniu do pszenicy ozimej. Świadczy to o dużej wrażliwości jęczmienia i żyta na wahania plonu. Natomiast zmiana o jednostkę plonu pszenicy ozimej spowoduje wzrost lub spadek dochodu bez dopłat o 4,4\%. Jednostkowa zmiana ceny (o 1 zł) najsilniejszy wpływ będzie miała na dochód z uprawy jęczmienia jarego. Jego poziom może wzrosnąć lub spaść o 5,5\%. Natomiast w przypadku żyta i pszenicy ozimej oddziaływanie wahań ceny będzie słabsze. Ocenia się, że prognozowany na 2022 rok poziom dochodu bez dopłat z uprawy żyta może podlegać zmianie o $+/-4,5 \%$, a $z$ uprawy pszenicy ozimej o $+/-3,9 \%$. Rozpatrując wpływ jednostkowej zmiany kosztów uprawy (o 100 zł/ha) na poziom dochodu, należy stwierdzić, 
że zdecydowanie największą wrażliwością charakteryzuje się jęczmień jary. Wzrost lub spadek kosztów o 100 zł od poziomu wynikającego z trendu, w badanych gospodarstwach spowoduje wzrost lub spadek dochodu bez dopłat o $11,2 \%$. Na drugiej pozycji znalazło się żyto - dochód będzie podlegał zmianom o $+/-10,8 \%$. Wzrost lub spadek o 100 zł kosztów uprawy 1 ha pszenicy ozimej będzie skutkować wahaniami dochodu o $+/-5,1 \%$.

Tabela 3. Procentowe zmiany w wynikach projekcji zbóż na 2022 rok ze względu na jednostkowe zmiany plonu, ceny i kosztów w próbie badawczej gospodarstw

Table 3. Percentage changes in the projection results of cereals for 2022 due to unit changes in yield, prices and costs in the research sample of farms

\begin{tabular}{|c|c|c|c|c|c|c|}
\hline \multirow{2}{*}{ Wyszczególnienie } & \multicolumn{2}{|c|}{ Plon, dt/ha } & \multicolumn{2}{|c|}{ Cena, zł/dt } & \multicolumn{2}{|c|}{ Koszty, zł/ha } \\
\hline & $+1 \mathrm{dt}$ & $-1 \mathrm{dt}$ & $+1 \mathrm{zl}$ & $-1 \mathrm{zl}$ & $+100 \mathrm{zl}$ & $-100 \mathrm{zl}$ \\
\hline \multicolumn{7}{|c|}{ Pszenica ozima } \\
\hline Dochód z działalności bez dopłat & $+4,4$ & $-4,4$ & $+3,9$ & $-3,9$ & $-5,1$ & $+5,1$ \\
\hline Wskaźnik opłacalności & $+1,5$ & $-1,5$ & $+1,3$ & $-1,3$ & $-2,5$ & $+2,7$ \\
\hline \multicolumn{7}{|c|}{ Żyto ozime } \\
\hline Dochód z działalności bez dopłat & $+6,8$ & $-6,8$ & $+4,5$ & $-4,5$ & $-10,8$ & $+10,8$ \\
\hline Wskaźnik opłacalności & $+2,4$ & $-2,4$ & $+1,6$ & $-1,6$ & $-5,5$ & $+6,2$ \\
\hline \multicolumn{7}{|c|}{ Jęczmień jary } \\
\hline Dochód z działalności bez dopłat & $+8,1$ & $-8,1$ & $+5,5$ & $-5,5$ & $-11,2$ & $+11,2$ \\
\hline Wskaźnik opłacalności & $+2,1$ & $-2,1$ & $+1,4$ & $-1,4$ & $-3,7$ & $+4,0$ \\
\hline
\end{tabular}

Źródło: opracowanie własne na podstawie badań własnych.

Podobnie jak dochód zmianie podlega również opłacalność uprawy zbóż w ujęciu ilorazowym (relacja wartości produkcji do kosztów ogółem). Procentowe zmiany wskaźnika opłacalności - bez względu na czynnik je wywołujący - będą większe w przypadku żyta i jęczmienia niż pszenicy.

\section{Podsumowanie}

Przez prognozowanie przyszłych zdarzeń dąży się do minimalizowania ryzyka, które towarzyszą podejmowanym decyzjom. Wyniki projekcji sporządzonej na 2022 rok $\mathrm{w}$ warunkach przeciętnych, tzn. wynikających $\mathrm{z}$ tendencji długookresowej wskazują na poprawę wyników produkcyjnych i cenowych badanych zbóż, tj. pszenicy ozimej, żyta ozimego oraz jęczmienia jarego. Biorąc pod uwagę skumulowany wpływ obu zmiennych, ocenia się, że w 2022 roku - w porównaniu do roku bazowego dla projekcji - najsilniejszy wzrost przychodów liczonych na 1 ha odnotuja producenci żyta $(43,2 \%)$, a następnie pszenicy ozimej $(31,9 \%)$ i jęczmienia jarego $(21,9 \%)$. Koszty uprawy wzrosną od $21,8 \%$ w przypadku żyta do $22,9 \%$ - w odniesieniu do jęczmienia. W rezultacie ekonomiczna efektywność produkcji pszenicy i żyta będzie wyższa niż w roku bazowym dla projekcji, odpowiednio o 10,8 i 23,0 p.p., podczas gdy jęczmienia jarego obniży się - o 1,1 p.p.

Od tych ogólnych tendencji moga jednak występować odchylenia, których nie można przewidzieć, np. ze względu na zmienność warunków klimatycznych, czy szczególnie silne wahania cen produktów lub cen środków produkcji. Wyniki badań wskazują, że żyto 
i jęczmień jary charakteryzuje relatywnie duża wrażliwość na każdy z czynników dochodotwórczych, tj. plon, cenę sprzedaży ziarna oraz koszty uprawy. Natomiast w przypadku pszenicy ozimej siła ich oddziaływania była słabsza. Świadczą o tym odchylenia (in plus lub in minus) dochodu i wskaźnika opłacalności wynikające z jednostkowych zmian plonu, ceny i kosztów uprawy.

Postępujące procesy integracji i globalizacji powoduja, że mechanizm kształtowanie się cen surowców rolnych jest determinowany nie tylko przez relacje popytowo-podażowe w kraju, ale również przez sytuację na tzw. rynkach światowych (Hamulczuk, Gędek i Stańko, 2012). Jak wiadomo poziom krajowych cen roślinnych surowców rolnych jest funkcją wielu czynników, do których można zaliczyć m.in. ceny światowe, dlatego też $\mathrm{w}$ procesie prognozowania opłacalności produkcji roślinnej w Polsce należy uwzględniać także tendencje na rynkach światowych oraz występujących $\mathrm{w}$ ramach stowarzyszeń gospodarczych. Stwierdzono, że projekcja wyników zbóż na 2022 rok w próbie gospodarstw w Polsce, w pewnym zakresie zbieżna jest z prognozą Komisji Europejskiej, która przewiduje wzrost plonów i cen sprzedaży zbóż. W konsekwencji należy również spodziewać się wyższej ich opłacalności.

\section{Literatura}

Allen, P.G. (1994). Economic forecasting in agriculture. International Journal of Forecasting, 10 (1), 81-135.

Baer-Nawrocka, A., Kiryluk-Dryjska, E. (2015). Produkcja zbóż w wybranych krajach Unii Europejskiej uwarunkowania strukturalne i polityczne (Cereals production in selected European Union countries political and structural implications). J. Agribus. Rural Dev., 4(38), 617-625.

Dittmann, P. (2004). Prognozowanie na podstawie szeregów czasowych (Forecasting based on time series). W: M. Cieślak (red.) Prognozowanie gospodarcze. Metody i zastosowania (Economic forecasting. Methods and applications) (s. 62-103). Wydawnictwo Naukowe PWN, Warszawa.

European Commission (2016). EU Agricultural Outlook. Prospect for EU agricultural markets and income 2016-2026. December.

European Commission (2018). EU Crops Market Observatory. Pobrano 10 stycznia 2018 z: https://ec.europa.eu/ agriculture/market-observatory/crops en.

Eurostat (2015). Statistics on agricultural markets. Pobrane 25 czerwca 2015 z: http://ec.europa.eu/agriculture/ markets-and-prices/market-statistics/index_en.htm.

Filipiak, K. (2009). Ilościowe metody prognozowania w rolnictwie (Quantitative forecasting methods in agriculture). W: I. Marcinkowska (red.) Kierunki zmian w produkcji roślinnej w Polsce do roku 2020 (s. 9-18). Stud. Rap. IUNG-PIB, 14

Główny Urząd Statystyczny (2017). Rocznik Statystyczny Rzeczypospolitej Polskiej (Statistical Yearbook of the Republic of Poland). Zakład Wydawnictw Statystycznych.

Hamulczuk, M., Gędek, S., Stańko, S. (2012). Prognozowanie cen surowców rolnych na podstawie zależności przyczynowych (Forecasting prices of agricultural raw materials based on causal relationships). Program Wieloletni 2011-2014, 52, Warszawa: IERiGŻ-PIB.

Hamulczuk, M., Klimkowski, C., Stańko, S. (2013). Metody ilościowe w systemie prognozowania cen produktów rolnych (Quantitative methods in the price forecasting system for agricultural products). Program Wieloletni 2011-2014, 89, Warszawa: IERiGŻ-PIB.

Kisielińska, J. (2012). Podstawy ekonometrii w Excelu (Basics of econometrics in Excel). Wydawnictwo SGGW Warszawa.

Majewski, E. (2010). Produkcyjne, ekonomiczne i środowiskowe aspekty uproszczenia struktury zasiewów (Selected production, economic and environmental aspects of crop rotations). Roczniki Nauk Rolniczych Seria $G, 97,(3), 159-169$

Prospects for Agricultural Markets in the EU 2017-2030. (2017). Pobrano 10 stycznia 2018 z: https://ec.europa.eu/agriculture/sites/agriculture/files/markets-and-prices/medium-termoutlook/2017/2017-tables.pdf. 
Skarżyńska, A., Pietrych, Ł. (2017). Projekcja opłacalności produkcji zbóż i rzepaku w perspektywie 2022 roku (Projection of profitability of cereals and rape production in the perspective of 2022). Roczniki Naukowe Ekonomii Rolnictwa i Rozwoju Obszarów Wiejskich, 104, (2), 50-63.

Sobczyk, M. (1976). Zagadnienie prognozowania plonów w świetle literatury (The Problem of Crops Prognosis in Literature). Annales Universitatis Mariae Curie-Skłodowska. Sectio H, Oeconomia, 10, 183-200.

Sobczyk, M. (1991). Statystyczne metody prognozowania (Statistical Methods of Prediction). Annales Universitatis Mariae Curie-Skłodowska. Sectio H, Oeconomia, 25, 337-354.

Sobczyk, M. (2008). Prognozowanie. Teoria, przykłady, zadania (Forecasting. Theory, examples, tasks). PLACET, Warszawa.

Stańko, S. (1999). Prognozowanie w rolnictwie (Forecasting in agriculture). Wyd. 2, SGGW, Warszawa.

Stańko, S., Hamulczuk, M. (2013). Estymacja i weryfikacja modelu ekonometrycznego (Estimation and verification of the econometric model). W: S. Stańko (red.) Prognozowanie w agrobiznesie. Teoria i przykłady zastosowania (s. 77-97). Wydawnictwo SGGW, Warszawa.

Do cytowania / For citation:

Skarżyńska A., Pietrych Ł. (2018). Projekcja opłacalności uprawy zbóż w Polsce w 2022 roku na tle prognozy produkcji zbóż w Unii Europejskiej do 2030 roku. Problemy Rolnictwa Światowego, 18(1), 224-234; DOI: 10.22630/PRS.2018.18.1.21

Skarżyńska A., Pietrych Ł. (2018). Direct Projection of Profitability of Cereal Crops in Poland in 2022 against the Forecast of Cereal Production in the European Union in 2030 (in Polish). Problems of World Agriculture, 18(1), 224-234; DOI: 10.22630/PRS.2018.18.1.21 